\title{
T Cell Epitope Mapping Study With Insulin Overlapping Peptides Using ELISPOT Assay in Japanese Children and Adolescents With Type 1 Diabetes
} TAKASHI HIGASHIDE, TOMOYUKI KAWAMURA, MASAO NAGATA, REIKO KOTANI, KAYO KIMURA, MASAKAZU HIROSE,
HIROSHI INADA, SHIZUHIRO NIIHIRA, AND TSUNEKAZU YAMANO

Department of Pediatrics [T.H., T.K., M.H., H.I., T.Y.], Osaka City University Graduate School of Medicine, Osaka 545-8585, Japan; Department of Development and Aging [M.N., R.K.], Division of Internal and Geriatric Medicine, Kobe University Graduate School of Medicine, 650-0017 Kobe, Japan; Interdisciplinary Studies for Advanced Aged Society [K.K.], Social Services and Clinical Psychology [S.N.], Osaka City University Graduate School of Human Life Science, Osaka 558-8585, Japan

\begin{abstract}
Type 1 diabetes (T1D) is a T cell-mediated autoimmune disease. Insulin seems to be a critical antigen recognized by autoreactive $\mathrm{T}$ cells. In this study, we performed $\mathrm{T}$ cell epitope mapping of insulin using serial overlapping peptides in Japanese patients with T1D. Serial overlapping insulin peptides comprising 23 peptides, which were each 15 -amino acid long, were prepared based on insulin sequence. Cytokine secretion from peripheral $\mathrm{T}$ cells against these peptides was studied by enzyme-linked immunospot (ELISPOT) assay in 18 patients with recent-onset T1D and 12 patients with established T1D, and compared with 17 healthy control subjects. In ELISPOT assay, IFN- $\gamma$-secreting T cells, but not IL-4, against several insulin peptides were observed in $77.8 \%$ of patients with recent-onset $\mathrm{T} 1 \mathrm{D}, 50.0 \%$ of patients with established T1D, and $0 \%$ of healthy control subjects. All epitopes recognized by $\mathrm{T}$ cells were identified in the B-chain of insulin. The most frequent epitope existed at the B10-24 region (9/18), followed by B1-15 and B11-25 regions (6/18, each), with B4-18, B9-23, and B12-26 identified in some patients. These data did not correlate with insulin autoantibodies or HLA-DRB1 of the patients. This is the first report of $\mathrm{T}$ cell epitope mapping using one amino acid serial overlapping peptides of insulin in T1D. ELISPOT assay revealed the frequent existence of insulin peptide-specific $\mathrm{T}$ cells in patients with recent-onset and established T1D. The T cell epitopes of insulin were similar but not identical in our cohort, which probably explains the difficulty encountered in prevention of human T1D by using insulin. (Pediatr Res 59: 445-450, 2006)
\end{abstract}

$\mathrm{I}_{\mathrm{i}}^{\mathrm{n}}$ n type 1 diabetes (T1D), T cells are thought to be involved in the destruction of pancreatic beta cells (1). However, it is impossible to prove the direct role of T cells in human T1D. There is sufficient evidence for the direct role of $\mathrm{T}$ cells in the destruction of pancreatic beta cells in studies using a mouse model of nonobese diabetes (NOD) (2-4). In this model, $\mathrm{T}$ cell clones derived from mice with experimentally-induced insulitis can induce beta cell destruction both in vitro and in vivo.

Received August 16, 2005; accepted October 25, 2005

Correspondence: Tomoyuki Kawamura, M.D., Ph.D., Department of Pediatrics, Osaka City University Graduate School of Medicine, 1-4-3 Asahimachi, Abeno-ku, Osaka 545-8585, Japan; e-mail: kawam@med.osaka-cu.ac.jp

This work was supported in part by Grants-in-Aid 13670828 from the Ministry of Education, Culture, Sports, Science, and Technology of Japan.

DOI: 10.1203/01.pdr.0000200803.72985.3c
Insulin, GAD, and insulinoma-associated tyrosine phosphatase-like protein-2 (IA-2) are considered major autoantigens based on research on autoantibodies (1). Interestingly, several studies have reported the detection of autoreactive $\mathrm{T}$ cells against the same antigens (5). Among these autoantigens, insulin is the only pancreatic beta cell-specific protein and may be important. The majority of $\mathrm{T}$ cells infiltrating beta cells in NOD mice recognize insulin (6). Moreover, in this model, intranasal, s.c., aerosol, or oral administration of insulin provides protection against pancreatic beta cell damage $(7,8)$. It has been recently reported that insulin prophylaxis against human T1D fails to provide such protection (9). The administered dose of insulin or selection of prediabetic subjects might account for this failure. Further studies are required to determine the role of insulin in human T1D. The purpose of the present study was to determine the quantity and quality of frequency of insulin-specific $\mathrm{T}$ cells and to analyze their epitopes.

The enzyme-linked immunospot (ELISPOT) assay is a sensitive tool for detecting antigen-specific $\mathrm{T}$ cells. We previously developed an immunoglobulin-free ELISPOT assay, which had a low background, and reported that this method could detect GAD-specific T cells in human T1D $(10,11)$. In this report, ELISPOT assay was performed using serial overlapping insulin peptides in Japanese patients with T1D.

\section{METHODS}

Subjects. The study protocol was approved by the Human Ethics Review Committee of Osaka City University Graduate School of Medicine. Informed consent was obtained from the parents of 18 patients with recent-onset juvenile T1D ( 8 males aged $4-15 \mathrm{y}$ and 10 females aged $4-15 \mathrm{y}$; mean age, $8.8 \pm 3.5 \mathrm{y}, \pm \mathrm{SD}), 12$ patients with established juvenile T1D (4 males aged $5-15 \mathrm{y}$ and 8 females aged $3-15 \mathrm{y}$; mean age, $10.8 \pm 4.2 \mathrm{y})$, and 17 healthy control subjects ( 7 males aged $3-16$ y and 10 females aged $0-15$ y; mean age, $7.9 \pm 5.0 \mathrm{y}$ ) (Tables 1-3). Patients were considered to have recent-onset

Abbreviations: ELISPOT, enzyme-linked immunospot; IA, insulin antibody; IAA, insulin autoantibody; IA-2, insulinoma-associated tyrosine phosphatase-like protein-2; NOD, nonobese diabetic; PBMCs, peripheral blood mononuclear cells; PHA, phytohemagglutinin; PPD, purified protein derivative; SI, stimulation index; T1D, type 1 diabetes 
juvenile T1D when insulin treatment commenced within $2 \mathrm{wk}$ before enrollment in the present study. The criteria used for the diagnosis for T1D were diabetic ketosis and ketoacidosis, polyuria, polydipsia, and weight loss, followed by assessment of serum autoantibody levels. Healthy control subjects were matched with MHC and age of recent-onset of patients as much as possible.

Antibodies. Serum antibodies to GAD and IA-2 were measured by the Cosmic GAD antibody RIA kit (Cosmic, Tokyo, Japan) and the IA-2 immunoprecipitation assay kit (Cosmic), respectively $(12,13)$. The normal ranges of GAD and IA-2 antibodies determined in healthy Japanese blood donors are $<1.5$ units $/ \mathrm{mL}$ and $<0.4$ units $/ \mathrm{mL}$, respectively. Insulin autoantibody (IAA) and insulin antibody (IA) were assayed with the liquid-phase radio-binding assay, as described previously (14). The results were expressed as nanounits band insulin specifically precipitated per $\mathrm{ml}$ of serum ( $\mathrm{n}$ units $/ \mathrm{mL}$ ). The mean $+3 \mathrm{SD}$ of 404 healthy subjects, $200 \mathrm{n}$ units $/ \mathrm{mL}$, was used to define the normal range. IA induced by insulin administration could not be distinguished from IAA.

HLA typing. HLA typing of DRB1* alleles was performed using a locus-specific PCR amplification procedure as described previously by Erlich et al. (15).

Peptide synthesis and antigens. Serial overlapping peptides based on insulin sequence were synthesized by using the Multipin ${ }^{\mathrm{TM}}$ peptide system (Mimotopes, Victoria, Australia): 7 peptides from the A chain of insulin and 16 peptides from the $B$ chain of insulin, which were each 15 -amino acid long (Table 4). Recombinant human insulin was obtained from Sigma Chemical Co.-Aldrich (Tokyo, Japan). Phytohemagglutinin (PHA) was purchased from Wako Chemicals (Osaka, Japan) and purified protein derivative (PPD) of Mycobacterium tuberculosis was obtained from Nippon BCG (Tokyo).

Isolation of peripheral blood mononuclear cells and culture medium. Heparinized peripheral blood samples withdrawn from the subjects were assayed within $3 \mathrm{~h}$ of collection. Peripheral blood mononuclear cells (PBMCs) were isolated by centrifugation through Lymphocyte Separation Medium (ICN Biomedicals, Inc., Aurora, OH). The isolated lymphocytes were cultured in RPMI 1640 medium supplemented with $10 \%$ heatinactivated human $\mathrm{AB}$ serum, $2 \mathrm{mM}$ of L-glutamine, $100 \mu \mathrm{g} / \mathrm{mL}$ of streptomycin, $100 \mathrm{U} / \mathrm{mL}$ of penicillin, $1 \mathrm{mM}$ of sodium pyruvate, and $5 \times 10^{-5} \mathrm{M}$ of $\beta$-mercaptoethanol (hereafter designated complete medium [CM]). The human type $\mathrm{AB}$ serum was filtered through the Cellulose Easter Membrane (Spectrum Medical Industries Inc., Houston, TX) to remove substances with molecular weight $>100,000$ including immunoglobulins, resulting in the presence of less than $2 \mu \mathrm{g} / \mathrm{mL}$ total IgG.

Cell proliferation assay. Freshly isolated PBMCs were cultured at $2 \times$ $10^{5}$ /well in 96-well round-bottom plates (Costar; Corning Inc., Corning, NY) with one of various stimulants added to each well at $37^{\circ} \mathrm{C}, 5 \% \mathrm{CO}_{2}$ atmosphere in $200 \mu \mathrm{L}$ of $\mathrm{CM}$. In this study, the antigens were used at the following final concentrations: $20 \mu \mathrm{M}$ insulin peptides, $10 \mu \mathrm{g} / \mathrm{mL}$ whole insulin, $1 \mu \mathrm{g} / \mathrm{mL}$ PPD, $10 \mu \mathrm{g} / \mathrm{mL}$ PHA or free of antigens. After 6-d culture (except $3 \mathrm{~d}$ for PHA), each well was pulsed with $1 \mu \mathrm{Ci}$ tritiated thymidine ([3H]; sp. act. $68 \mathrm{Ci} / \mathrm{mmol}$; ICN Biomedicals, Inc., Irvine, CA) for the final $15 \mathrm{~h}$. The cells were then harvested and the radioactivity was measured by a microplate reader (1450 Micro Beta Trirux; Wallac Oy). All measurements were conducted in triplicates and the results were expressed as the stimulation index (SI), which represented the mean cpm in the presence of antigen/mean cpm in the absence of the antigen. A positive response was defined as an SI $\geq 3$.

ELISPOT assay. The ELISPOT assay was performed as described previously $(10,11)$. Briefly, nitrocellulose-bottomed 96 -well microtiter plates were coated with $15 \mu \mathrm{g} / \mathrm{mL}$ of either mouse anti-human IFN- $\gamma$ MAb (MAb) (1-DIK, Mabtech AB, Stockholm, Sweden) or mouse anti-human IL-4 MAb (IL-4-I, Mabtech AB) in sterile PBS overnight at $4^{\circ} \mathrm{C}$. Unbound antibodies were removed by washing 6 times with sterile PBS. Aliquots of $2 \times 10^{5}$ PBMCs per well were incubated in MAb-coated plates with $20 \mu \mathrm{M}$ insulin peptides, $10 \mu \mathrm{g} / \mathrm{mL}$ whole insulin, $1 \mu \mathrm{g} / \mathrm{mL}$ PPD, $10 \mu \mathrm{g} / \mathrm{mL}$ PHA, or wells free of antigens and stimulants. After $40 \mathrm{~h}$ of incubation at $37^{\circ} \mathrm{C}, 5 \% \mathrm{CO}_{2}$ and washing, $1 \mu \mathrm{g} / \mathrm{mL}$ of biotinconjugated anti-cytokine MAb (7-B6-1 for IFN- $\gamma$ and IL4-II for IL-4) was added to each well and incubated for $3 \mathrm{~h}$ at room temperature followed by 1-hincubation after adding streptavidin conjugated with alkaline phosphatase. Finally, BCIP/NBT substrate solution (Bio-Rad Laboratories, Richmond, CA) was added, kept for 15-25 min until a color change was noted, and then washed to stop the reaction. Spots were counted using an National Institutes of Health imager with a CCD camera, and data were expressed as mean values of triplicate determinations for each antigen and lymphocyte concentration. The number of spots obtained as a result of antigen stimulation was determined as [(mean number of spots in the presence of antigen) - (mean number of spots without stimulation)] and referred to here as "antigen-stimulated." When the number of spots was greater than the mean $+3 \mathrm{SD}$ of the controls, it was considered a positive response. Background represented the number of spots without stimulation. To exclude those responses influenced by the high background, the response that was less than two times lower than the background was considered negative regardless of the cut-off value. In this study, we applied the immunoglobulin-free ELISPOT assay to detect antigen-specific T cells $(10,11)$. In this method, the background is minimum. The mean numbers of IFN- $\gamma$ and IL- 4 spots in wells containing only T cells were $0.28 \pm 0.38$ and $0.24 \pm 0.58$ per $2 \times 10^{5}$ PBMCs, respectively.

Statistical analysis. For the proliferation and ELISPOT assay, the results of two groups were compared using the Mann-Whitney U test, while the results of three groups were compared with the Kruskal-Wallis test. Spearman's correlation coefficient was used when comparing two nonparametric variables. The $\chi^{2}$ test was used to compare the proportion of T cells among the groups. For cases in which the expected values were $<5$, the Fisher's exact test was used. One-way factorial ANOVA and multiple comparison tests were used to compare the ranges of the proliferative responses and the reaction in ELISPOT assay to positive controls (PPD and PHA) among the groups. All data are expressed as mean $\pm \mathrm{SD}$. P values $<0.05$ were deemed statistically significant.

Table 1. Age, sex, HLA, serum autoantibody levels to islet autoantigens, and HbAlc of recent-onset type 1 diabetic patients ( $n=18$ )

\begin{tabular}{|c|c|c|c|c|c|c|c|}
\hline Subject & $\begin{array}{l}\text { Age } \\
\text { (years) }\end{array}$ & Sex & $\begin{array}{c}\text { HLA } \\
\text { DRB1:alleles }\end{array}$ & \multicolumn{3}{|c|}{ Autoantibody $\dagger$} & $\begin{array}{l}\mathrm{HbA1c} \dagger \\
(\%)\end{array}$ \\
\hline P2 & 4 & M & DRB $1 * 09012 / * 15021$ & 2084 & $<1.5$ & 5.9 & 11.5 \\
\hline P3 & 4 & $\mathrm{~F}$ & DRB $1 * 08021 / * 08032$ & 211 & $<1.5$ & 123.8 & 15.6 \\
\hline P4 & 5 & M & DRB $1 * 04051 / * 09012$ & 258 & 11.1 & $<0.4$ & 11.6 \\
\hline P7 & 8 & $\mathrm{~F}$ & DRB1*0403/*0406 & 1359 & 16.1 & 2.7 & 10.7 \\
\hline P8 & 8 & $\mathrm{~F}$ & DRB $1 * 0101 / * 08021$ & 21 & 30.4 & $<0.4$ & 12.9 \\
\hline P9 & 9 & M & DRB $1 * 04051 / * 0407$ & 53 & 1.9 & $<0.4$ & 14.5 \\
\hline $\mathrm{P} 10$ & 9 & $\mathrm{~F}$ & DRB $1 * 04051 / * 09021$ & ND & 1.7 & 14.0 & 12.5 \\
\hline P11 & 10 & M & $\mathrm{DRB} 1 * 04051 / * 08021$ & 36 & 1.8 & 710.1 & 13.5 \\
\hline $\mathrm{P} 12$ & 10 & M & DRB $1 * 04051 / * 09012$ & 2227 & $<1.5$ & 38.2 & 7.7 \\
\hline P17 & 15 & M & DRB $1 * 04051 / * 09012$ & 4 & 86.7 & 304.8 & 13.7 \\
\hline P18 & 15 & $\mathrm{~F}$ & $\mathrm{DRB} 1 * 04051$ & 169 & 16.4 & ND & 17.0 \\
\hline
\end{tabular}

ND, not done.

$\dagger$ Data of autoantibody and HbA1c were measured at the onset of overt diabetes. 
Table 2. Age, sex, duration of diabetes, HLA, and serum antibody levels of established type 1 diabetic patients $(n=12)$

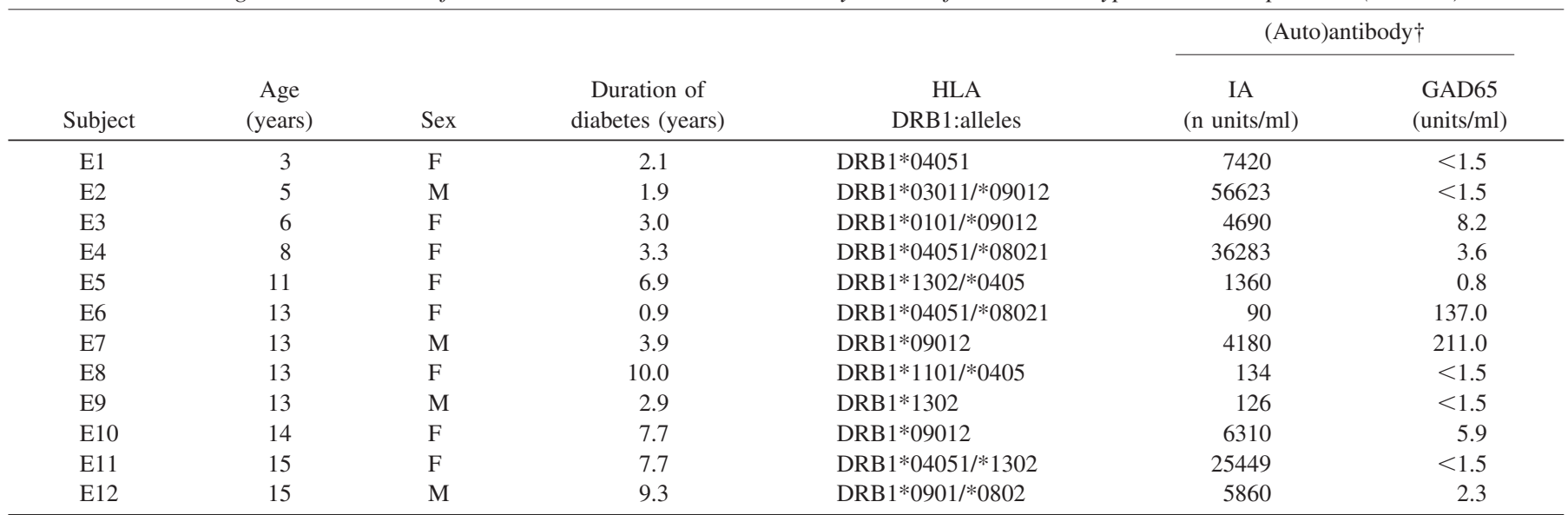

IA, insulin antibody.

$\dagger$ The (Auto)antibodies were assayed at the same time of ELISPOT assay.

Table 3. Age, sex, HLA, and serum autoantibody levels to islet autoantigens of healthy control subjects $(n=17)$

\begin{tabular}{|c|c|c|c|c|c|}
\hline \multirow[b]{2}{*}{ Subject } & \multirow[b]{2}{*}{$\begin{array}{l}\text { Age } \\
\text { (years) }\end{array}$} & \multirow[b]{2}{*}{ Sex } & \multirow[b]{2}{*}{$\begin{array}{c}\text { HLA } \\
\text { DRB1:alleles }\end{array}$} & \multicolumn{2}{|c|}{ Autoantibody } \\
\hline & & & & $\begin{array}{c}\text { IAA } \\
\text { (n units/ml) }\end{array}$ & $\begin{array}{c}\text { GAD65 } \\
\text { (units/ml) }\end{array}$ \\
\hline $\mathrm{C} 1$ & 0 & $\mathrm{~F}$ & DRB1*09012/*15011 & 2 & $<1.5$ \\
\hline $\mathrm{C} 2$ & 2 & $\mathrm{~F}$ & DRB $1 * 04051 / * 1405$ & 23 & $<1.5$ \\
\hline $\mathrm{C} 3$ & 3 & M & DRB $1 * 08032 / * 1301$ & 156 & $<1.5$ \\
\hline $\mathrm{C} 4$ & 3 & $\mathrm{~F}$ & DRB $1 * 04051 / * 08021$ & 34 & $<1.5$ \\
\hline $\mathrm{C} 5$ & 4 & M & DRB1*04051/*09012 & 69 & $<1.5$ \\
\hline C6 & 4 & $\mathrm{~F}$ & DRB $1 * 04051 / * 08021$ & 122 & $<1.5$ \\
\hline $\mathrm{C} 7$ & 4 & $\mathrm{~F}$ & DRB $1 * 09012 / * 1405$ & 81 & $<1.5$ \\
\hline $\mathrm{C} 8$ & 7 & $\mathrm{~F}$ & DRB1*0701/*1201 & 77 & $<1.5$ \\
\hline $\mathrm{C} 9$ & 8 & $\mathrm{~F}$ & DRB $1 * 04051 / * 08021$ & 40 & $<1.5$ \\
\hline $\mathrm{C} 10$ & 9 & M & DRB1*0406/*09012 & 178 & $<1.5$ \\
\hline $\mathrm{C} 11$ & 10 & $\mathrm{~F}$ & DRB1*0406/*08021 & 66 & $<1.5$ \\
\hline $\mathrm{C} 12$ & 11 & M & DRB $1 * 0410 / * 09012$ & 8 & $<1.5$ \\
\hline $\mathrm{C} 13$ & 11 & $\mathrm{~F}$ & DRB1*04051/*09012 & 110 & $<1.5$ \\
\hline $\mathrm{C} 14$ & 14 & M & DRB $1 * 04051 / * 1403$ & 82 & $<1.5$ \\
\hline $\mathrm{C} 15$ & 14 & $\mathrm{M}$ & DRB1*08021/*09012 & 64 & $<1.5$ \\
\hline $\mathrm{C} 16$ & 15 & $\mathrm{~F}$ & DRB $1 * 0407 / * 08021$ & 119 & $<1.5$ \\
\hline $\mathrm{C} 17$ & 16 & M & DRB $1 * 04051 / * 09021$ & 24 & $<1.5$ \\
\hline
\end{tabular}

$\mathrm{ND}$, not done.

\section{RESULTS}

Patients' profiles and HLA typing. The clinical characteristics of all subjects are listed in Tables 1-3. DRB1*0405, DRB $1 * 0802$, and DRB $1 * 0901$, which represent the diabetes susceptible haplotypes in Japanese T1D (16). were identified in $16 / 18$ patients with recent-onset T1D and $11 / 12$ patients with established T1D. DRB1*1502, which is one of the protective haplotypes, was identified in $1 / 18$ patient with recent-onset T1D. In the healthy control subjects, 1 of 17 had the protective haplotype of DRB $1 * 1501$, and 15 of 17 had susceptible haplotypes, similar to recent-onsets T1D.

IAA, GAD and IA-2 antibodies were positive in $6 / 16$ (37.5\%), 12/18 (66.7\%), and 12/15 (80.0\%) of the tested patients with recent-onset T1D, respectively. In comparison, IA and GAD antibodies were positive in $9 / 12(75.0 \%)$ and
Table 4. Amino acid sequences of insulin peptides

\begin{tabular}{cccc}
\hline A chain: G-I-V-E-Q-C-C-T-S-I-C-S-L-Y-Q-L-E-N-Y-C-N \\
Peptides & Sequence & Peptides & Sequence \\
\hline $\mathrm{A}_{1-15}$ & GIVEQCCTSICSLYQ & $\mathrm{A}_{5-19}$ & QCCTSICSLYQLENY \\
$\mathrm{A}_{2-16}$ & IVEQCCTSICSLYQL & $\mathrm{A}_{6-20}$ & CCTSICSLYQLENYC \\
$\mathrm{A}_{3-17}$ & VEQCCTSICSLYQLE & $\mathrm{A}_{7-21}$ & CTSICSLYQLENYCN \\
$\mathrm{A}_{4-18}$ & EQCCTSICSLYQLEN & & \\
\hline B chain: F-V-N-Q-H-L-C-G-S-H-L-V-E-A-L-Y-L-V-C-G-E-R-G-F-F-Y-T-P-K-T \\
Peptides & Sequence & Peptides & Sequence \\
\hline $\mathrm{B}_{1-15}$ & FVNQHLCGSHLVEAL & $\mathrm{B}_{9-23}$ & SHLVEALYLVCGERG \\
$\mathrm{B}_{2-16}$ & VNQHLCGSHLVEALY & $\mathrm{B}_{10-24}$ & HLVEALYLVCGERGF \\
$\mathrm{B}_{3-17}$ & NQHLCGSHLVEALYL & $\mathrm{B}_{11-25}$ & LVEALYLVCGERGFF \\
$\mathrm{B}_{4-18}$ & QHLCGSHLVEALYLV & $\mathrm{B}_{12-26}$ & VEALYLVCGERGFFY \\
$\mathrm{B}_{5-19}$ & HLCGSHLVEALYLVC & $\mathrm{B}_{13-27}$ & EALYLVCGERGFFYT \\
$\mathrm{B}_{6-20}$ & LCGSHLVEALYLVCG & $\mathrm{B}_{14-28}$ & ALYLVCGERGFFYTP \\
$\mathrm{B}_{7-21}$ & CGSHLVEALYLVCGE & $\mathrm{B}_{15-29}$ & LYLVCGERGFFYTPK \\
$\mathrm{B}_{8-22}$ & GSHLVEALYLVCGER & $\mathrm{B}_{16-30}$ & YLVCGERGFFYTPKT \\
\hline
\end{tabular}

7/12 (58.3\%) of the tested patients with established T1D. None of the control subjects was positive for these autoantibodies.

PBMCs proliferation in the presence of medium alone, $P H A$, and PPD. Cell proliferation in stimulant-free media was similar in recent-onset T1D, established T1D, and control (Table 5). PHA and PPD were used as positive control. A high proliferative response to PHA was observed in both patient groups and the control (Table 5) and no significant difference in the response to PHA was observed among the three groups. There was no significant difference in the response to PPD among the three groups (SI range; 1.6-77.3, Table 5).

$T$ cell proliferation response to whole insulin and serial overlapping insulin peptides. No T cell proliferation response to whole insulin was observed in patients with recent-onset and established T1D as well as the control group (SI; $0.89 \pm$ $0.20,1.08 \pm 0.25$, and $0.87 \pm 0.23, p=0.16$, respectively). The SIs of $\mathrm{T}$ cell proliferation responses to the serial overlapping insulin peptides of the A chain of insulin were less than 3 in all subjects. Furthermore, 2/12 patients ( $\mathrm{P} 2$ responded to B10-24, P14 responded to B10-24 and B11-25) with recent- 
Table 5. Proliferative responses of PBMCs in the presence of medium alone, PHA, and PPD, and IFN- $\gamma$ secretion induced by medium and by PPD antigen in ELISPOT assay

\begin{tabular}{|c|c|c|c|c|c|c|}
\hline \multirow[b]{2}{*}{ Subjects } & \multirow[b]{2}{*}{$\begin{array}{c}\text { Age } \\
\text { (years) }\end{array}$} & \multicolumn{3}{|c|}{ Proliferation assay } & \multicolumn{2}{|c|}{ ELISPOT assay (IFN- $\gamma$ ) } \\
\hline & & $\begin{array}{l}\text { Medium alone } \\
\quad(\mathrm{cpm})\end{array}$ & PHA (SI) & PPD (SI) & \multicolumn{2}{|c|}{$\left(\right.$ spot $\left./ 2 \times 10^{5} \mathrm{PBMCs}\right)$} \\
\hline Healthy control $(n=17)$ & $7.9 \pm 5.0$ & $451 \pm 151$ & $338.5 \pm 49.7$ & $24.6 \pm 15.3$ & $0.3 \pm 0.5$ & $25.3 \pm 24.4$ \\
\hline Established T1D $(\mathrm{n}=12)$ & $10.8 \pm 4.2$ & $392 \pm 114$ & $276.4 \pm 156.0$ & $26.8 \pm 19.6$ & $0.4 \pm 0.4$ & $15.3 \pm 20.1$ \\
\hline Recent-onset T1D $(\mathrm{n}=18)$ & $8.8 \pm 3.5$ & $489 \pm 309$ & $278.7 \pm 88.3$ & $21.6 \pm 26.0$ & $0.3 \pm 0.4$ & $14.7 \pm 12.6$ \\
\hline $\mathrm{P} 1$ & 4 & 415 & 307.8 & 26.5 & 0 & 1.0 \\
\hline P2 & 4 & 334 & 418.6 & 1.6 & 0.3 & 1.3 \\
\hline P3 & 4 & ND & $\mathrm{ND}$ & ND & 0.3 & 2.3 \\
\hline P4 & 5 & 388 & 357.3 & 10.4 & 0 & 12.0 \\
\hline P5 & 6 & 565 & 213.4 & 1.7 & 1.0 & 2.0 \\
\hline P6 & 6 & 401 & 342.5 & 77.3 & 0.6 & 24.7 \\
\hline $\mathrm{P} 7$ & 8 & 1364 & 136.3 & 9.8 & 0 & 23.0 \\
\hline P8 & 8 & ND & ND & ND & 0 & 50.0 \\
\hline P9 & 9 & 237 & 405.9 & 15.1 & 0.3 & 21.0 \\
\hline P10 & 9 & ND & ND & ND & 1.0 & 30.0 \\
\hline P11 & 10 & 326 & 228.3 & 9.6 & 0 & 10.7 \\
\hline P12 & 10 & 500 & 228.5 & 72.7 & 0.3 & 12.3 \\
\hline P13 & 10 & ND & ND & ND & 0 & 18.0 \\
\hline P14 & 10 & 457 & 276.4 & 6.9 & 0 & 9.0 \\
\hline P15 & 12 & 703 & 238.4 & 5.8 & 1.0 & 20.0 \\
\hline P16 & 13 & ND & ND & ND & 0.3 & 1.3 \\
\hline P17 & 15 & ND & ND & ND & 0 & 9.0 \\
\hline P18 & 15 & 180 & 190.7 & 21.9 & 0 & 17.0 \\
\hline
\end{tabular}

ND, not done.

Data are mean $\pm \mathrm{SD}$.

onset T1D showed positive $\mathrm{T}$ cell proliferation against certain insulin peptides of the insulin B chain, whereas no positive response was noted in patients with established T1D and in the healthy control subjects.

PHA and PPD stimulation in the ELISPOT assay. In the ELISPOT assay, PHA and PPD were used as positive control antigens. PHA stimulation generated large numbers of IFN- $\gamma$ (>100/well) and IL-4 (>100/well) spots in all three groups of subjects. No difference was observed among the responses of the three groups. Stimulation with PPD resulted in a variable number of IFN- $\gamma$ spots $\left(0-70\right.$ per $2 \times 10^{5}$ PBMCs, Table 5$)$, whereas no IL-4 spots were detected in any of the three groups.

Overlapping insulin peptides-reactive $T$ cells in the ELISPOT assay. In the IL-4 ELISPOT assay, no positive spots against all overlapping insulin peptides were observed in all subjects. On the other hand, the IFN- $\gamma$ ELISPOT assay showed positive spots against overlapping peptides of the insulin B chain. Positive IFN- $\gamma$ spots were detected in $77.8 \%$ $(14 / 18)$ of patients with recent-onset T1D, 50.0\% (6/12) of patients with established T1D, and $0 \%(0 / 17)$ of healthy control subjects (Fig. 1). Figure 2 shows the positive spots for each peptide in patients with recent-onset and established T1D. Among the patients with recent-onset T1D, 33.3\% $(6 / 18)$ were noted to have insulin B1-15-stimulated IFN- $\gamma$ spots, $16.7 \%$ (3/18) showed B4-18-stimulated IFN- $\gamma$ spots, $5.6 \%$ (1/18) showed B8-22-stimulated IFN- $\gamma$ spots, $16.7 \%$ (3/18) had B9-23-stimulated IFN- $\gamma$ spots, 50.0\% (9/18) had B10-24-stimulated IFN- $\gamma$ spots, 33.3\% (6/18) had B11-25stimulated IFN- $\gamma$ spots, and $16.7 \%$ (3/18) showed B12-26stimulated IFN- $\gamma$ spots. Among the patients with established T1D, 8.3\% (1/12) had B4-18-stimulated IFN- $\gamma$ spots, $16.7 \%$
(2/12) had B5-19-stimulated IFN- $\gamma$ spots, $16.7 \%(2 / 12)$ had B10-24-stimulated IFN- $\gamma$ spots, 33.3\% (4/12) had B11-25stimulated IFN- $\gamma$ spots, $16.7 \%$ (2/12) had B12-26-stimulated IFN- $\gamma$ spots, $8.3 \%$ (1/12) had B15-29-stimulated IFN- $\gamma$ spots, and $8.3 \%(1 / 12)$ had B16-30-stimulated IFN- $\gamma$ spots.

Correlation between results of ELISPOT assay and data of HLA typing and antibodies. Among the recent-onset T1D patients who had at least one of the susceptible HLA haplotypes, such as DRB1*0405, DRB1*0802, and DRB1*0901, $75.0 \%$ patients were positive in the insulin peptide stimulated ELISPOT assay, including one patient who had resistant HLA DRB1*1502. Therefore, neither positive nor negative effect of
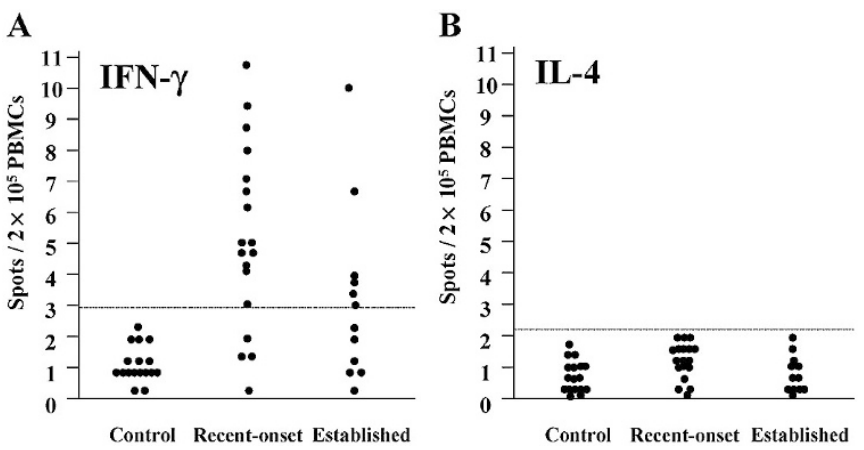

Figure 1. Cytokine secretion induced by insulin peptides in ELISPOT assay. Each dot indicates the number of the maximum of IFN- $\gamma(A)$ and IL-4 $(B)$ spots in the data of each subject. Tests were performed in triplicates in each patient. The stimulated spots represented the [(mean number of spots in the presence of antigen) - (mean number of spots in the absence of stimulation)]. Each horizontal line represents the mean $+3 \mathrm{SD}$ of the control population (IFN- $\gamma$ 2.92, IL-4 2.17). Control: healthy control subjects ( $n=17)$; Recentonset: patients with recent-onset juvenile T1D $(n=18)$; Established: patients with established juvenile T1D $(n=12)$. 


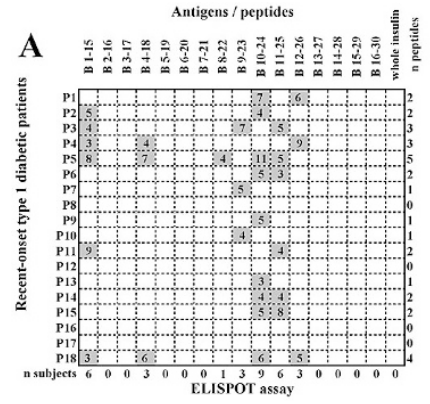

B

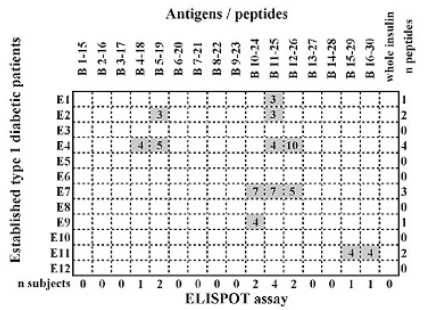

Figure 2. ELISPOT assay analysis of IFN- $\gamma$ production responses to whole insulin and each of the insulin peptides (16 peptides from the insulin B chain of 15 amino acids) in patients with recent-onset T1D $(A)$ and those with established T1D $(B)$. Tests were performed in triplicates in each patient. The stimulated spots represented the [(mean number of spots in the presence of antigen) - (mean number of spots in the absence of stimulation)]. When the number of spots was greater than the mean $+3 \mathrm{SD}$ of the controls, it was considered a positive response. To exclude that the response was influenced by the high background, the response that was less than two times lower than the background was considered negative regardless of the cut-off value. Only positive responses are shown as grey bars with numbers, which indicate the number of spots. All subjects of the control group showed negative responses to all prepared peptides.

HLA haplotypes was observed as a result of insulin peptide stimulated ELISPOT assay. Five patients (55.6\%) among 9 recent-onset T1D patients who showed B10 epitope, had DRB $1 * 0405$ most frequently. However, there was no statistical correlation between the epitope region and HLA haplotypes.

Among six patients with recent-onset T1D who were positive in IAA, $5(83.3 \%)$ showed a positive spot in peptide stimulated ELISPOT assay. Eight patients (80.0\%) among 10 with recent-onset T1D and negative IAA also showed positive in ELISPOT assay. Therefore, there was no significant correlation between the results of ELISPOT assay and IAA. Similarly, IA, GAD antibody, and IA-2 did not correlate with the results of ELISPOT assay.

\section{DISCUSSION}

In the present study, we first described the clinical features of young Japanese patients with T1D because there are known differences between Japanese T1D and Caucasian T1D.(17) The incidence of Japanese T1D is much lower than that in Caucasians (18). The disease susceptibility HLA haplotypes in Japanese T1D are different from that in Caucasians (16). In the present study, only three of 30 patients with T1D did not have the susceptible type of DRB1 gene and the prevalence rates of the three major autoantibodies were similar to those reported in previous studies (19). Therefore, the subjects examined in our study were considered representative of Japanese patients with T1D. Healthy control subjects in this study were matched with MHC of T1D subjects.

$\mathrm{T}$ cell proliferation against whole insulin in the peripheral blood of T1D subjects is very difficult (20). In the present study, $\mathrm{T}$ cells significantly responded to the insulin sequencebased peptides but not to whole insulin. One possibility is that the biologic effect of whole insulin on cultured cells may affect the assay in vitro. Alternatively, the processed portion of insulin by antigen presenting cells might not be effective to reveal antigenic sequences recognized by $\mathrm{T}$ cells. The proliferation assay used for detecting antigen-specific $\mathrm{T}$ cells was reported to be less sensitive than ELISPOT assay (21). Several recent studies adopted the ELISPOT assay for detection of autoreactive $\mathrm{T}$ cells in T1D $(10,11,22,23)$. In our study, ELISPOT assay using overlapping insulin peptides detected autoimmune reactions against insulin in recent-onset T1D (77.8\%) as well as the autoantibodies. The response in ELISPOT assay does not just depend on hyperactivity, because there are no differences in the reactions to PHA and PPD between T1D and healthy control subjects. These T cell responses to insulin peptides are not likely to be due to insulin therapy because all patients with recent-onset T1D were examined within $2 \mathrm{wk}$ of commencement of insulin therapy. In particular, six of 18 patients ( $\mathrm{P} 3, \mathrm{P} 4, \mathrm{P} 7, \mathrm{P} 9, \mathrm{P} 11, \mathrm{P} 13)$ were tested just before insulin therapy and they had positive ELISPOT assay. In this regard, in none of the patients did a negative test change to a positive test at repeated assays during the course of insulin therapy.

Previous studies reported an inverse relationship between cellular and humoral responses to autoantigens $(20,24,25)$. However, among patients with recent-onset T1D, we did not find any relationship among HLA haplotypes, IAA, GAD antibodies, and IA-2 antibodies. The difference between the studies is probably due to the high sensitivity of ELISPOT assay or the relatively lower titer of IAA.

In addition, among our 12 patients with established T1D, $6(50 \%)$ were positive against insulin peptides according to ELISPOT assay. These results suggest that the ELISPOT assay is the most positive in patients with short disease duration and still detects a positive response after longer duration. Furthermore, the positive regions of both diabetic groups were similar implying that memory $\mathrm{T}$ cells remain in peripheral blood several years after the development of T1D.

No positive response in ELISPOT assay against insulin peptides was observed in healthy control subjects who had T1D susceptible MHC haplotypes. Therefore, positive response in T1D was not likely to be due to T1D susceptible MHC.

Several studies have focused on $\mathrm{T}$ cell epitope of insulin and preproinsulin peptides in Caucasian T1D patients. For the assay of $\mathrm{CD}^{+}{ }^{+}$and $\mathrm{CD} 8^{+} \mathrm{T}$ cells, $8-11$ and $12-16$ amino acid long peptides, respectively, were usually applied. Some groups reported several $\mathrm{CD} 8^{+} \mathrm{T}$ cell epitopes $(26,27)$. Although we did not rule out $\mathrm{CD} 8^{+}$response in our assay, we focused on 15-amino acid long peptides in our study. Among the 12-16 amino acid long peptides, the epitopes of $\mathrm{B} 9-23$, $\mathrm{B} 20-\mathrm{C} 4$, and B24-C36 were reported to be detected by peripheral $\mathrm{T}$ cells $(22,28,29)$. Furthermore, B11-27 and C5-20 were recognized by $\mathrm{T}$ cell clones $(30,31)$. Recent studies reported that $\mathrm{T}$ cell clone established from pancreatic lymph nodes recognized a particular epitope A1-15 (32). In particular, B9-23 was considered the main epitope of T cells both in mouse and human T1D. However, in the present study, B10-24 epitope was observed much more frequently than B9-23 epitope. This might be just because no study has previously applied B10-24 peptides in T cell epitope research. 
Otherwise, differences in the disease susceptible HLA class II between Japanese and Caucasians may explain this finding. Furthermore, several previous studies have tried $\mathrm{T}$ cell epitope mapping of insulin in T1D using serial peptides. However, in those studies several amino acids were changed among serial peptides. Therefore, this is the first report of human $\mathrm{T}$ cell epitope mapping in T1D using complete series of overlapping peptides of insulin. Our study revealed that the epitope regions of insulin exist at three regions near the B1, B4, and B10 regions and the epitopes varied in each individual patient. Interestingly, peptides with only one amino acid difference induced different results in the same patient. Recent studies have clearly suggested that $\mathrm{T}$ cells show different types of activation in recognition of altered ligands for $\mathrm{T}$ cell receptors (33). Yokomizo and colleagues (34) showed previously that human $\mathrm{CD}^{+}$helper $\mathrm{T}$ cell clones responded to altered peptides, in which a single residue was altered, following the secretion of different cytokines. Another study showed that two peptides that were otherwise identical apart from a single amino acid induced different types of T cells; one was T helper 1, while the other was Thelper 2 (35). Thus, it seems that even a single amino acid difference is critical for $\mathrm{T}$ cell recognition and reaction. Taken together, the various $\mathrm{T}$ cell epitopes in each patient might at least in part correlate with the heterogeneity of this disease, and may also explain the failure of the insulin prevention trial (9).

In this study, we could not apply assays that use isolated T cells but PMBC, because different types of peptides were examined simultaneously. Therefore, for characterizing responding $\mathrm{T}$ cells, further studies, such as blocking assay or cloning $\mathrm{T}$ cells, are needed.

Acknowledgments. The authors thank Mr. H. Murayama and coworkers at Diagnostics Department of Yamasa Corporation for assaying IAA and IA.

\section{REFERENCES}

1. Castaño L, Eisenbarth GS 1990 Type-I diabetes: a chronic autoimmune disease of human, mouse, and rat. Annu Rev Immunol 8:647-679

2. Nagata M, Santamaria P, Kawamura T, Utsugi T, Yoon JW 1994 Evidence for the role of $\mathrm{CD}^{+}$cytotoxic $\mathrm{T}$ cells in the destruction of pancreatic $\beta$-cells in nonobese diabetic mice. J Immunol 152:2042-2050

3. Wong FS, Visintin I, Wen L, Flavell RA, Janeway CA Jr 1996 CD8 T cell clones from young nonobese diabetic (NOD) islets can transfer rapid onset of diabetes in NOD mice in the absence of CD4 cells. J Exp Med 183:67-76

4. Haskins K, McDuffie M 1990 Acceleration of diabetes in young NOD mice with a $\mathrm{CD}^{+}{ }^{+}$islet-specific T cell clone. Science 249:1433-1436

5. Panagiotopoulos C, Trudeau JD, Tan R 2004 T-cell epitopes in type 1 diabetes. Curr Diab Rep 4:87-94

6. Wegmann DR, Norbury-Glaser M, Daniel D 1994 Insulin-specific T cells are a predominant component of islet infiltrates in pre-diabetic NOD mice. Eur J Immunol 24:1853-1857

7. Daniel D, Wegmann DR 1996 Protection of nonobese diabetic mice from diabetes by intranasal or subcutaneous administration of insulin peptide B-(9-23). Proc Natl Acad Sci USA 93:956-960

8. Harrison LC, Dempsey-Collier M, Kramer DR, Takahashi K 1996 Aerosol insulin induces regulatory CD8 $\gamma \delta \mathrm{T}$ cells that prevent murine insulin-dependent diabetes. J Exp Med 184:2167-2174

9. Diabetes Prevention Trial - Type 1 Diabetes Study Group 2002 Effects of insulin in relatives of patients with type 1 diabetes mellitus. N Engl J Med 346:1685-1691

10. Kotani R, Nagata M, Moriyama H, Nakayama M, Yamada K, Chowdhury SA, Chakrabarty S, Jin Z, Yasuda H, Yokono K 2002 Detection of GAD65-reactive T-Cells in type 1 diabetes by immunoglobulin-free ELISPOT assays. Diabetes Care 25:1390-1397

11. Kotani R, Nagata M, Imagawa A, Moriyama H, Yasuda H, Miyagawa J, Hanafusa $\mathrm{T}$, Yokono K $2004 \mathrm{~T}$ lymphocyte response against pancreatic beta cell antigens in fulminant Type 1 diabetes. Diabetologia 47:1285-1291
12. Powell M, Prentice L, Asawa T, Kato R, Sawicka J, Tanaka H, Petersen V, Munkley A, Morgan S, Rees Smith B, Furmaniak J 1996 Glutamic acid decarboxylase autoantibody assay using ${ }^{125}$ I-labelled recombinant $\mathrm{GAD}_{65}$ produced in yeast. Clin Chim Acta 256:175-188

13. Masuda M, Powell M, Chen S, Beer C, Fichna P, Smith BR, Furmaniak J 2000 Autoantibodies to IA-2 in insulin-dependent diabetes mellitus. Measurements with a new immunoprecipitation assay. Clin Chim Acta 291:53-66

14. Vardi P, Dib SA, Tuttleman M, Connelly JE, Grinbergs M, Radizabeh A, Riley WJ, Maclaren NK, Eisenbarth GS, Soeldner JS 1987 Competitive insulin autoantibody assay. Prospective evaluation of subjects at high risk for development of type 1 diabetes mellitus. Diabetes 36:1286-1291

15. Erlich H, Bugawan T, Begovich AB, Scharf S, Griffith R, Saiki R, Higuchi R, Walsh PS 1991 HLA-DR, DQ and DP typing using PCR amplification and immobilized probes. Eur J Immunogenet 18:33-55

16. Sugihara S, Sakamaki T, Konda S, Murata A, Wataki K, Kobayashi Y, Minamitani K, Miyamoto S, Sasaki N, Niimi H 1997 Association of HLA-DR, DQ genotype with different $\beta$-cell functions at IDDM diagnosis in Japanese children. Diabetes 46:1893-1897

17. Ito T, Nakamura K, Umeda E, Kaino Y, Hirai H, Kida K, Mimura G 2001 Familial predisposition of type 1 diabetes mellitus in Japan, a country with low incidence. the Japan Diabetes Society Data Committee for Childhood Diabetes J Pediatr Endocrinol Metab 14:589-595

18. Karvonen M, Viik-Kajander M, Moltchanova E, Libman I, LaPorte R, Tuomilehto J 2000 Incidence of childhood type 1 diabetes worldwide. Diabetes Mondiale (DiaMond) Project Group Diabetes Care 23:1516-1526

19. Sera Y, Kawasaki E, Abiru N, Ozaki M, Abe T, Takino H, Kondo H, Yamasaki H, Yamaguchi Y, Akazawa S, Nagataki S, Uchigata Y, Matsuura N, Eguchi K 1999 Autoantibodies to multiple islet autoantigens in patients with abrupt onset type 1 diabetes and diabetes diagnosed with urinary glucose screening. J Autoimmun 13:257-265

20. Dubois-LaForgue D, Carel JC, Bougnères PF, Guillet JG, Boitard C 1999 T-cell response to proinsulin and insulin in type 1 and pretype 1 diabetes. J Clin Immunol 19:127-134

21. Schmittel A, Keilholz U, Scheibenbogen C 1997 Evaluation of the interferon- $\gamma$ ELISPOT-assay for quantification of peptide specific $\mathrm{T}$ lymphocytes from peripheral blood. J Immunol Methods 210:167-174

22. Alleva DG, Crowe PD, Jin L, Kwok WW, Ling N, Gottschalk M, Conlon PJ, Gottlieb PA, Putnam AL, Gaur A 2001 A disease-associated cellular immune response in type 1 diabetics to an immunodominant epitope of insulin. J Clin Invest 107:173-180

23. Herzog BA, Ott PA, Dittrich MT, Quast S, Karulin AY, Kalbacher H, Karges W, Tary-Lehmann M, Lehmann PV, Boehm BO, Durinovic-Bello I 2004 Increased in vivo frequency of IA-2 peptide-reactive IFN $\gamma^{+} / \mathrm{IL}-4^{-} \mathrm{T}$ cells in type 1 diabetic subjects. J Autoimmun 23:45-54

24. Schloot NC, Roep BO, Wegmann D, Yu L, Chase HP, Wang T, Eisenbarth GS 1997 Altered immune response to insulin in newly diagnosed compared to insulin-treated diabetic patients and healthy control subjects. Diabetologia 40:564-572

25. Roep BO, Duinkerken G, Schreuder GM, Kolb H, de Vries RR, Martin S 1996 HLA-associated inverse correlation between $\mathrm{T}$ cell and antibody responsiveness to islet autoantigen in recent-onset insulin-dependent diabetes mellitus. Eur J Immunol 26:1285-1289

26. Rathmann S, Rajasalu T, Rosinger S, Schlosser M, Eiermann T, Boehm BO, Durinovic-Bello I 2004 Preproinsulin-specific CD8 + T cells secrete IFNgamma in human type 1 diabetes. Ann N Y Acad Sci 1037:22-25

27. Toma A, Haddouk S, Briand JP, Camoin L, Gahery H, Connan F, Dubois-Laforgue D, Caillat-Zucman S, Guillet JG, Carel JC, Muller S, Choppin J, Boitard C 2005 Recognition of a subregion of human proinsulin by class I-restricted T cells in type 1 diabetic patients. Proc Natl Acad Sci USA 102:10581-10586

28. Durinovic-Belló I, Boehm BO, Ziegler AG 2002 Predominantly recognized proinsulin $\mathrm{T}$ helper cell epitopes in individuals with and without islet cell autoimmunity. J Autoimmun 18:55-66

29. Rudy G, Stone N, Harrison LC, Colman PG, McNair P, Brusic V, French MB, Honeyman MC, Tait B, Lew AM 1995 Similar peptides from two $\beta$ cell autoantigens, proinsulin and glutamic acid decarboxylase, stimulate $\mathrm{T}$ cells of individuals at risk for insulin-dependent diabetes. Mol Med 1:625-633

30. Schloot NC, Willemen S, Duinkerken G, de Vries RR, Roep BO 1998 Cloned T cells from a recent onset IDDM patient reactive with insulin B-chain. J Autoimmun. 11:169175

31. Semana G, Gausling R, Jackson RA, Hafler DA 1999 T cell autoreactivity to proinsulin epitopes in diabetic patients and healthy subjects. J Autoimmun 12:259-267

32. Kent SC, Chen Y, Bregoli L, Clemmings SM, Kenyon NS, Ricordi C, Hering BJ, Hafler DA 2005 Expanded T cells from pancreatic lymph nodes of type 1 diabetic subjects recognize an insulin epitope. Nature 435:224-228

33. Nishimura Y, Chen YZ, Uemura Y, Tanaka Y, Tsukamoto H, Kanai T, Yokomizo H, Yun C, Matsuoka T, Irie A, Matsushita S 2004 Degenerate recognition and response of human $\mathrm{CD}^{+}$Th cell clones: implications for basic and applied immunology. Mol Immunol 40:1089-1094

34. Yokomizo H, Matsushita S, Fujisao S, Murakami S, Fujita H, Shirouzu M, Yokoyama S, Ogawa M, Nishimura Y 1997 Augmentation of immune response by an analog of the antigenic peptide in a human T-cell clone recognizing mutated Ras-derived peptides. Hum Immunol 52:22-32

35. Nishimura Y, Chen YZ, Kanai T, Yokomizo H, Matsuoka T, Matsushita S 1998 Modification of human T-cell responses by altered peptide ligands: a new approach to antigen-specific modification. Intern Med 37:804-817 